\title{
Investigation on outcomes and bacterial distributions of liver cirrhosis patients with gram-negative bacterial bloodstream infection
}

\author{
Yangxin Xie ${ }^{1,2, *}$, Bo Tu${ }^{2, *}$, Xin Zhang ${ }^{2}$, Jingfeng $\mathrm{Bi}^{3}$, Lei Shi ${ }^{2}$, Peng Zhao ${ }^{2}$, Weiwei \\ Chen $^{2}$, Suxia Liu ${ }^{4}$, Dongping $X_{u^{3}}$ and Enqiang Qin ${ }^{1}$ \\ ${ }^{1}$ Treatment and Research Center for Infectious Diseases, Beijing 302 Hospital, Beijing, China \\ ${ }^{2}$ Chinese PLA General Hospital, Medical School, Beijing, China \\ ${ }^{3}$ Research Center for Clinical and Translational Medicine, Beijing 302 Hospital, Beijing, China \\ ${ }^{4}$ Treatment and Research Center for Liver Failure, Beijing 302 Hospital, Beijing, China \\ *These authors have contributed equally to this work \\ Correspondence to: Dongping $\mathrm{X} U$, email: $x u d o n g p i n g 302 @ s i n a . c o m$ \\ Enqiang Qin, email: qeq2004@sina.com \\ Keywords: liver cirrhosis; gram-negative bacterial bloodstream infection; nosocomial infection \\ Received: March 15, $2017 \quad$ Accepted: June 04, $2017 \quad$ Published: December 22, 2017 \\ Copyright: Xie et al. This is an open-access article distributed under the terms of the Creative Commons Attribution License 3.0 (CC \\ BY 3.0), which permits unrestricted use, distribution, and reproduction in any medium, provided the original author and source are \\ credited.
}

\section{ABSTRACT}

Objective: The study aimed at analyzing the epidemiology and outcomes of liver cirrhosis patients undergoing gram-negative bacterial bloodstream infection.

Results: Totally 508 eligible patients were collected, with $25.79 \%$ 30-day mortality, and $\mathbf{5 8 . 8 6 \%}$ patients were confirmed as nosocomial infection. The most common isolates were Escherichia coli (48.29\%) and Klebsiella pneumoniae $(19.29 \%)$, and multidrug-resistant isolates accounted for $36.61 \%$. The bacterial distributions were similar between survivors and non-survivors $(P>0.05)$, but showed close association with acquisition sites of infection $(P<0.05)$. Nosocomial infection $(H R=1.589,95 \% C I=1.004-2.517)$, Child-Pugh grade $(H R=2.471,95 \% C I=1.279-$ 4.772), septic shock $(H R=1.966,95 \% C I=1.228-3.146)$, complications $(H R=3.529$, 95\% CI=2.140-5.818), and WBC ( $\mathrm{HR}=1.065,95 \% \mathrm{CI}=1.018-1.114)$ were independent indicators for 30-day mortality. $\beta$-lactamase inhibitor antibiotics exerted a high antibacterial activity.

Methods: The inpatients with liver cirrhosis developed gram-negative bacterial bloodstream infection were collected. The clinical characteristics, bacterial distribution and drug sensitivity results of patients were compared according to their 30-day survival status and acquisition sites of infections. Cox regression model was applied to evaluate the risk factors for 30-day mortality.

Conclusion: Escherichia coli and Klebsiella pneumoniae are frequently isolated from gram-negative bacterial bloodstream infection episodes in cirrhosis patients. Acquisition site of infection can influence clinical characteristics and etiological distribution. $\beta$-lactamase inhibitor antibiotics may be the first choice for empirical treatments.

\section{INTRODUCTION}

Liver cirrhosis is a big threat to people's health in China. It is well known that China has a high HBV infection rate [1]. According to the statistics, there are about 120 million hepatitis B surface antigen (HBsAg) carriers and nearly 300,000 individuals die from HBVrelated liver diseases each year in China [2]. Bloodstream 
infection (BSI) may be responsible for the high mortality [3]. BSI is one of the serious complications of cirrhosis, representing an important reason for liver failure and death. It has been reported that the occurrence of infection in cirrhosis patients is 10 times more than that in noncirrhosis individuals [4]. Several risk factors have been confirmed to be connected with the development of BSI in liver cirrhosis patients, such as liver failure, long time of hospital stay, spontaneous bacterial peritonitis (SBP) history, and advanced cirrhosis stage, etc $[3,5]$. Timely and appropriate antibiotic treatments are vitally important for prognosis in liver cirrhosis patients developing to BSI [6]. Therefore, it is necessary to investigate the epidemiology of infection and antibiotics sensitivity, thus guiding treatments in liver cirrhosis patients.

The gram-negative bacteria such as Escherichia coli and Klebsiella pneumoniae are the leading causes for BSI, especially among those hospitalized patients [7]. Gram-negative bacterial infection is a serious challenge in clinic, and its incidence exists differences among different age groups, genders, and populations [8]. At the present time, the third-generation cephalosporin is believed to be the first choice for empirical treatments due to its high antibacterial activity to gram-negative bacteria and good tolerance [9]. However, it is worthy noting that the incidence of multidrug-resistant (MDR) gram-negative bacteria has been increasing in recent years, leading to antibacterial therapy failures and poor outcomes [1012]. In addition, the distribution of pathogens is distinct in different geographic locations, even in different hospitals located at the same district [13-15]. Therefore, the better knowledge about local epidemiology of gram negative bacteria infection is necessary. However, such a retrospective study with a large sample size is rarely reported in China.

Nosocomial infection is a kind of infection occurring in the hospital environments, such as general wards, ICU, operating rooms, etc, which is resulted from various risk factors, including older age, surgical intervention, and prolonged hospital stays [16]. It has been demonstrated that about $8.7 \%$ hospitalized patients may suffer from the infections, and the rate has significantly increased in liver cirrhosis patients admitted to hospital [7, 17]. Previous studies have also reported that the bacterial distribution and antibiotic resistance are significantly different between nosocomial and community-acquired SBP [18]. However, few studies investigate the clinical and microbiological characteristics of gram-negative bacterial infection according to acquisition sites of infections.

In this study, we evaluated the microbiological epidemiology of gram-negative bacterial BSI and potential risk factors for 30-day mortality in liver cirrhosis patients. In addition, the antibiotic susceptibility tests were also performed. The present study was scheduled in Beijing
302 hospital of China, one of the largest infectious disease hospitals in China. Tens of thousands of patients from all over the country are admitted to the hospital for cirrhosis annually. Thus, the results obtained in this study had a certain representation.

\section{RESULTS}

\section{Baseline characteristics of the included patients}

During the study period, 508 eligible patients were enrolled in the current study, including 390 males $(76.77 \%)$ and 118 females $(23.23 \%)$, with the average age of $50.96 \pm 11.47$ years of age. Among these patients, 82 of them $(16.14 \%)$ were admitted to ICU unit (Table 1).

HBV was the most common reason for liver cirrhosis, which accounted for $64.76 \%$ and was followed by alcohol (11.81\%) and hepatitis C (10.04\%). Some of the patients presented liver failure $(23.42 \%)$ and other patients $(27.76 \%)$ were diagnosed with cirrhosis combined with hepatocellular carcinoma. According to Child-Pugh score, $9.05 \%$ patients were grouped to Class A and 33.07\% patients were grouped to Class B, while over half of the patients $(57.68 \%)$ were confirmed as Class C (Table 1$)$.

The baseline information of BSI is summarized in Table 1. More than half of the patients $(58.86 \%)$ were confirmed as nosocomial infection, and $20.28 \%$ patients were with infection history less than 2 years. Primary infection was the main source for BSI (accounting for $54.33 \%$ ), and SBP was the second source for infection (accounting for $40.16 \%$ ). Other infection sources included lung $(4.72 \%)$ and urinary tract $(0.79 \%)$. Fever was the most frequently observed symptom and $96.65 \%$ patients initially presented this symptom. Chilly occurred in $49.41 \%$ patients. Some complications were observed in the enrolled patients, containing hepatic encephalopathy $(12.40 \%)$ and hepato-renal syndrome (5.31\%). Furthermore, $9.25 \%$ patients were diagnosed with more than one complications, and $21.65 \%$ patients presented with septic shock (Table 1).

In addition, laboratory data suggested that the average WBC of eligible patients was $6.62 \pm 5.37$ $\left(\right.$ cells $\left.\times 10^{3} / \mu \mathrm{L}\right)$, while serum neutrophil was $69.68 \% \pm$ $16.57 \%$. Results in vitro experiments proved that $72.24 \%$ patients received appropriate antibiotics within $12 \mathrm{~h}$ (Table 1).

\section{Clinical characteristics of survivors and non- survivors}

The primary outcomes of enrolled patients were evaluated by using the 30-mortality. In the present study, 131 cirrhosis patients $(25.79 \%)$ died within 30 days after BSI diagnosis. The clinical characteristics were 
Table 1: Baseline characteristics of the study subjects

\begin{tabular}{|c|c|c|c|c|c|c|c|}
\hline \multirow[b]{2}{*}{ Features } & \multirow[b]{2}{*}{$\begin{array}{l}\text { Total case } \\
(n=508)\end{array}$} & \multicolumn{3}{|c|}{ Survival status } & \multicolumn{3}{|c|}{ Acquisition sites of infection } \\
\hline & & $\begin{array}{c}\text { Survivors, } \\
\mathbf{n}=\mathbf{3 7 7} \\
(\mathbf{7 4 . 2 1 \% )}\end{array}$ & $\begin{array}{c}\text { Non- } \\
\text { survivors, } \\
\text { n=131 } \\
(25.79 \%)\end{array}$ & $\boldsymbol{P}$ & $\begin{array}{c}\text { Nosocomial } \\
\text { BSI } \\
(n=299 \\
58.86 \%)\end{array}$ & $\begin{array}{l}\text { Community- } \\
\text { acquired BSI } \\
(n=209 \\
41.14 \%)\end{array}$ & $\boldsymbol{P}$ \\
\hline \multicolumn{8}{|l|}{$\begin{array}{l}\text { Demographic } \\
\text { characteristics }\end{array}$} \\
\hline Gender & & & & 0.203 & & & 0.517 \\
\hline Male & $390(76.77)$ & $294(77.98)$ & $95(72.52)$ & & $232(77.59)$ & $157(75.12)$ & \\
\hline Female & $118(23.23)$ & $83(22.02)$ & $36(37.48)$ & & $67(22.41)$ & $52(24.88)$ & \\
\hline Age (years) & $50.96 \pm 11.47$ & $50.73 \pm 10.96$ & $51.65 \pm 12.84$ & 0.021 & $50.68 \pm 11.80$ & $51.37 \pm 10.98$ & 0.502 \\
\hline Hospitalization unit & & & & 0.000 & & & 0.579 \\
\hline General ward & $426(83.86)$ & $350(92.84)$ & $76(58.02)$ & & $253(84.62)$ & $173(82.77)$ & \\
\hline $\mathrm{ICU}$ & $82(16.14)$ & $27(7.16)$ & $55(41.98)$ & & $46(15.38)$ & $36(17.22)$ & \\
\hline Liver diseases & & & & 0.561 & & & 0.171 \\
\hline Single Hepatitis B & $329(64.76)$ & $247965.52)$ & $82(62.59)$ & & $200(66.89)$ & $129(61.72)$ & \\
\hline Single Hepatitis C & $51(10.04)$ & $40(10.61)$ & $11(8.40)$ & & $29(9.70)$ & $22(10.53)$ & \\
\hline $\begin{array}{l}\text { Combined with } \\
\text { Hepatitis B and C }\end{array}$ & $8(1.58)$ & $7(1.86)$ & $1(0.76)$ & & $37(12.37)$ & $23(11.00)$ & \\
\hline Alcoholic & $60(11.81)$ & $41(10.87)$ & $19(14.50)$ & & $6(2.01)$ & $2(0.96)$ & \\
\hline Others & $60(11.81)$ & $42(11.14)$ & $18(13.74)$ & & $27(9.03)$ & $33(15.79)$ & \\
\hline $\begin{array}{l}\text { Combined with liver } \\
\text { failure (yes, n, \%) }\end{array}$ & $119(23.42)$ & $53(14.06)$ & $66(50.38)$ & 0.000 & $85(28.43)$ & $34(16.27)$ & 0.001 \\
\hline $\begin{array}{l}\text { Combined with } \\
\text { hepatocellular } \\
\text { carcinoma (yes, } \\
\mathrm{n}, \% \text { ) }\end{array}$ & $141(27.76)$ & $112(29.71)$ & $29(22.14)$ & 0.096 & $92(30.77)$ & $49(23.45)$ & 0.070 \\
\hline $\begin{array}{l}\text { Child-Pugh } \\
\text { classification }\end{array}$ & & & & 0.000 & & & 0.020 \\
\hline Class A & $46(9.05)$ & 44 (11.67) & $2(1.53)$ & & $35(11.71)$ & $11(5.26)$ & \\
\hline Class B & $168(33.07)$ & $150(39.79)$ & $19(14.50)$ & & $103(34.45)$ & $66(31.58)$ & \\
\hline Class C & $293(57.68)$ & $183(48.54)$ & $110(83.97)$ & & $161(53.85)$ & $132(63.16)$ & \\
\hline \multicolumn{8}{|l|}{ BSI data } \\
\hline $\begin{array}{l}\text { Infection history } \\
\text { within } 2 \text { years }\end{array}$ & & & & 0.263 & & & 0.000 \\
\hline Yes & $103(20.28)$ & $72(19.10)$ & $31(23.66)$ & & $45(15.05)$ & $58(27.75)$ & \\
\hline No & 405 (79.72) & 305 (80.90) & $100(76.34)$ & & $254(84.95)$ & $121(57.89)$ & \\
\hline BSI source & & & & 0.000 & & & 0.066 \\
\hline Primary & $276(54.33)$ & $221(58.62)$ & $55(41.98)$ & & $176(58.86)$ & $100(47.85)$ & \\
\hline Lung & $24(4.72)$ & $9(2.39)$ & $15(11.45)$ & & $14(4.68)$ & $10(4.78)$ & \\
\hline
\end{tabular}

(Continued) 


\begin{tabular}{|c|c|c|c|c|c|c|c|}
\hline \multirow[b]{2}{*}{ Features } & \multirow[b]{2}{*}{$\begin{array}{l}\text { Total case } \\
(n=508)\end{array}$} & \multicolumn{3}{|c|}{ Survival status } & \multicolumn{3}{|c|}{ Acquisition sites of infection } \\
\hline & & $\begin{array}{c}\text { Survivors, } \\
\mathbf{n}=\mathbf{3 7 7} \\
(\mathbf{7 4 . 2 1 \% )}\end{array}$ & $\begin{array}{c}\text { Non- } \\
\text { survivors, } \\
\mathbf{n}=131 \\
(25.79 \%)\end{array}$ & $\boldsymbol{P}$ & $\begin{array}{c}\text { Nosocomial } \\
\text { BSI } \\
(n=299 \\
58.86 \%)\end{array}$ & $\begin{array}{l}\text { Community- } \\
\text { acquired BSI } \\
(n=209 \\
41.14 \%)\end{array}$ & $\boldsymbol{P}$ \\
\hline Abdominal (SBP) & $204(40.16)$ & $143(37.93)$ & $61(46.56)$ & & $106(34.45)$ & $98(46.89)$ & \\
\hline Urinary tract & $4(0.79)$ & $4(1.06)$ & $0(0.00)$ & & $3(1.00)$ & $1(0.48)$ & \\
\hline \multicolumn{8}{|l|}{$\begin{array}{l}\text { Initial presenting } \\
\text { symptoms }\end{array}$} \\
\hline Fever (yes, n, \%) & $491(96.65)$ & $368(97.61)$ & $123(93.89)$ & 0.041 & $292(97.66)$ & $199(95.21)$ & 0.132 \\
\hline Chilly (yes, n, \%) & $251(49.41)$ & $201(53.32)$ & $50(38.17)$ & 0.003 & $157(52.51)$ & $94(44.98)$ & 0.095 \\
\hline Complications & & & & 0.000 & & & 0.147 \\
\hline All & $362(71.26)$ & $319(84.61)$ & $43(32.82)$ & & $215(71.91)$ & $147(70.33)$ & \\
\hline $\begin{array}{l}\text { Upper } \\
\text { gastrointestinal } \\
\text { bleeding }\end{array}$ & $9(1.77)$ & $4(1.06)$ & $5(3.82)$ & & $2(0.67)$ & $7(3.35)$ & \\
\hline $\begin{array}{l}\text { Hepatic } \\
\text { encephalopathy }\end{array}$ & $63(12.40)$ & $39(10.34)$ & $24(18.32)$ & & $35(11.71)$ & $28(13.40)$ & \\
\hline $\begin{array}{l}\text { Hepato-renal } \\
\text { syndrome }\end{array}$ & $27(5.31)$ & $7(1.86)$ & $20(15.27)$ & & $19(6.35)$ & $8(3.83)$ & \\
\hline $\begin{array}{l}\text { More than one } \\
\text { complication }\end{array}$ & $47(9.25)$ & $8(2.12)$ & $39(29.77)$ & & $28(9.36)$ & $19(9.09)$ & \\
\hline \multicolumn{8}{|l|}{ BSI severity } \\
\hline Septic shock & & & & 0.000 & & & 0.476 \\
\hline yes & $110(21.65)$ & $40(10.61)$ & $70(53.43)$ & & $68(22.74)$ & $42(20.10)$ & \\
\hline no & $398(78.35)$ & 337 (89.39) & $61(46.57)$ & & $231(77.26)$ & $167(79.90)$ & \\
\hline \multicolumn{8}{|l|}{ Laboratory data } \\
\hline $\mathrm{WBC}\left(\right.$ cells $\left.\times 10^{3} / \mu \mathrm{L}\right)$ & $6.62 \pm 5.37$ & $5.82 \pm 3.64$ & $8.92 \pm 8.19$ & 0.000 & $5.98 \pm 5.58$ & $7.52 \pm 4.93$ & 0.001 \\
\hline $\begin{array}{l}\text { Serum neutrophil } \\
(\%)\end{array}$ & $69.68 \pm 16.57$ & $68.68 \pm 16.31$ & $72.54 \pm 17.05$ & 0.021 & $0.63 \pm 0.15$ & $0.79 \pm 0.13$ & 0.000 \\
\hline $\begin{array}{l}\text { Appropriate } \\
\text { antibiotics within } 12 \mathrm{~h}\end{array}$ & & & & 0.008 & & & 0.016 \\
\hline Yes & $367(72.24)$ & $284(75.33)$ & $83(63.36)$ & & $204(68.23)$ & 163 (77.99) & \\
\hline No & $141(27.76)$ & $93(24.67)$ & $48(36.64)$ & & 95 (31.77) & $46(22.10)$ & \\
\hline $\begin{array}{l}\text { Nosocomial } \\
\text { infection (yes, n, \%) }\end{array}$ & $299(58.86)$ & $207(54.91)$ & $92(70.23)$ & 0.002 & - & - & - \\
\hline $\begin{array}{l}\text { 30-day survival } \\
\text { (survivors, } 1, \% \text { ) }\end{array}$ & $377(74.21)$ & - & - & - & $207(69.23)$ & $170(81.34)$ & 0.002 \\
\hline
\end{tabular}

Notes: ICU, Intensive care unit; BSI, Bloodstream infection; WBC, White blood cell; -, indicated no related data. 
compared between survivors and non-survivors. The results of analyses indicated that age, ICU admission, combined with liver failure, Child-Pugh score, the rate of nosocomial infection, BSI source, occurrence of fever and chilly, complications, septic shock, and laboratory data were significantly different between survivors and no-survivors $(P<0.05$ for all). Furthermore, patients receiving appropriate antibiotics within $12 \mathrm{~h}$ after BSI onset had a higher survival rate than those who were treated with impertinent antibiotics $(P=0.008)$. In addition, the gender rate, types of liver disease, and occurrence of hepatocellular carcinoma were similar between survivors and non-survivors $(P>0.05$ for all) (Table 1).

\section{Comparison of clinical characteristics between nosocomial and community-acquired infection}

Among the patients, 299 of them (58.86\%) were diagnosed with nosocomial BSI. The effects of acquisition sites of infection on clinical characteristics were investigated in the current study. Results demonstrated that Child-Pugh grade $(P=0.020)$, liver failure $(P=0.001)$, infection history within 2 years $(P=0.000)$, WBC $(P=0.001)$ and serum neutrophil $(P=0.000)$ were obviously different between nosocomial infection and communityacquired infection. Moreover, nosocomial infection was significantly correlated with inappropriate antibiotics within $12 \mathrm{~h}(P=0.016)$ and high 30 -day mortality $(P=0.002)$ (Table 1).

\section{Bacterial distributions of the survivors and non- survivors}

In our early study [19], Escherichia coli was the most common pathogen, which accounted for $48.23 \%$ and was followed by Klebsiella pneumoniae (19.29\%). Some other common isolates included Aeromomas species (5.91\%), Enterobacter cloacae (3.74\%), Acinetobacter baumanii (3.15\%), Pseudomonas aeruginosa (1.77\%), Stenotrophomonas maltophilia (1.18\%), and others (14.76\%). Additionally, $1.97 \%$ patients were proved to be infected by more than one pathogenic bacteria (Table 2).

ESBL statuses of Escherichia coli and Klebsiella pneumoniae were evaluated in the current study. Approximately $40.12 \%$ of Escherichia coli and Klebsiella pneumoniae presented positive ESBL and the rest (59.88\%) was negative (Table 2 ).

We compared the epidemiological distributions between survivors and non-survivors. The results suggested that the distribution of Acinetobacter baumanii was significantly different between survivors and nonsurvivors $(P=0.001)$, while the occurrence rate of other pathogens was similar between survivors and nonsurvivors $(P>0.05$ for all). In addition, the distribution of ESBL producing pathogens was also similar between survivors and non-survivors $(P=0.061)$ (Table 2$)$.

\section{Comparison of epidemiological distribution between nosocomial BSI and community- acquired BSI}

Chi-square test was applied to compare the distribution of pathogens between nosocomial BSI and community-acquired BSI. The results showed that the distributions of Klebsiella pneumoniae $(P=0.047)$, Pseudomonas aeruginosa $(P=0.011), \quad$ Enterobacter cloacae $(P=0.022)$, Acinetobacter baumanii $(P=0.018)$, Stenotrophomonas maltophilia $(P=0.039)$ and others $(P=0.046)$ were markedly different between patients diagnosed with nosocomial BSI and those who were confirmed to be community acquired BSI. However, the occurrence rates of Escherichia coli, Aeromonas species, and mixed were similar between the comparable groups ( $P>0.05$ for all). Additionally, the distribution of ESBL producing pathogens was similar between BSI acquired from different sites (Table 2).

\section{Drug sensitivity analysis}

Drug sensitivity test was carried out in the current study. About 91.65\% isolates were sensitive to Piperacillin/ tazobactam. Compared with Piperacillin/tazobactam, the isolated pathogens were more sensitive to carbapenems, with an average sensitive rate of $96.025 \%$, and Amikacin (96.62\%) $(P<0.05$ for both). In addition, the sensitive rates of cefepime $(75.97 \%)$, cefoperazone $(68.10 \%)$, cefotaxime $(64.65 \%)$, ceftazidime $(73.33 \%)$, ceftriaxone $(63.19 \%)$, gatifloxacin $(71.50 \%)$, and levofloxacin (70.25) were significantly lower than that of Piperacillin/tazobactam $(P<0.05$ for all) (Table 3$)$.

Additionally, the overall survival analyses were carried out for recruited patients in accordance with the $\beta$-lactamase inhibitors resistance of their isolated pathogens. Survival curves demonstrated that patients infected by piperacllin/tazobactam or cefperazone/ sulbactam resistant pathogens had a significantly poor survival rate (log rank test, $P<0.05$ for both) (Figures $1 \mathrm{~A}$ and $1 \mathrm{~B})$.

\section{Drug sensitivity analysis between nosocimial BSI and community-acquired BSI}

In the present study, we compared antibiotics sensitivity between pathogens isolated from nosocomial BSI and other sites. The results demonstrated that the pathogens isolated from hospital-acquired BSI had a higher resistant rate to carbapenems than those isolated from community-acquired BSI $(P<0.05)$. However, the drug resistances of other antibiotics were not influenced by the sites of infection ( $P>0.05$ for all) (Table 4$)$. 
Table 2: The distribution of bacteria among the study population

\begin{tabular}{|c|c|c|c|c|c|c|c|}
\hline & \multirow[b]{2}{*}{$\begin{array}{l}\text { Total, } \\
\mathrm{n}=\mathbf{5 0 8}\end{array}$} & \multicolumn{3}{|c|}{ Survival status } & \multicolumn{3}{|c|}{ Acquisition sites of infection } \\
\hline & & $\begin{array}{c}\text { Survivors, } \\
\mathbf{n}=\mathbf{3 7 7} \\
(\mathbf{7 4 . 2 1 \% )}\end{array}$ & $\begin{array}{c}\text { Non- } \\
\text { survivors, } \\
n=131 \\
(\mathbf{2 5 . 7 9 \% )}\end{array}$ & $\boldsymbol{P}$ & $\begin{array}{c}\text { Nosocomial } \\
\text { BSI, n=299 } \\
(\mathbf{5 8 . 8 6 \% )}\end{array}$ & $\begin{array}{c}\text { Community- } \\
\text { acquired BSI, } \\
n=209 \\
(41.14 \%)\end{array}$ & $\boldsymbol{P}$ \\
\hline \multicolumn{8}{|l|}{$\begin{array}{l}\text { Bacterial } \\
\text { distributions }\end{array}$} \\
\hline Escherichia coli & $\begin{array}{c}245 \\
(48.23)\end{array}$ & $185(49.07)$ & $60(45.80)$ & 0.519 & $135(45.15)$ & $110(52.63)$ & 0.097 \\
\hline $\begin{array}{l}\text { Klebsiella } \\
\text { pneumoniae }\end{array}$ & $98(19.29)$ & $72(19.10)$ & $26(19.85)$ & 0.851 & $49(16.39)$ & $49(23.45)$ & 0.047 \\
\hline $\begin{array}{l}\text { Pseudomonas } \\
\text { aeruginosa }\end{array}$ & $9(1.77)$ & $5(1.33)$ & $4(3.05)$ & 0.197 & $9(3.01)$ & $0(0.00)$ & 0.011 \\
\hline $\begin{array}{l}\text { Enterobacter } \\
\text { cloacae }\end{array}$ & $19(3.74)$ & $14(3.71)$ & $5(3.82)$ & 0.957 & $16(5.35)$ & $3(1.43)$ & 0.022 \\
\hline Aeromonas species & $30(5.91)$ & $24(6.37)$ & $6(4.58)$ & 0.455 & $15(5.02)$ & $15(7.18)$ & 0.309 \\
\hline $\begin{array}{l}\text { Acinetobacter } \\
\text { baumanii }\end{array}$ & $16(3.15)$ & $6(1.59)$ & $10(7.63)$ & 0.001 & $14(4.68)$ & $2(0.96)$ & 0.018 \\
\hline $\begin{array}{l}\text { Stenotrophomonas } \\
\text { maltophilia }\end{array}$ & $6(1.18)$ & $3(0.80)$ & $3(2.29)$ & 0.173 & $6(2.01)$ & $0(0.00)$ & 0.039 \\
\hline Others & $75(14.76)$ & $61(16.18)$ & $14(10.69)$ & 0.127 & $52(17.39)$ & $23(11.00)$ & 0.046 \\
\hline Mixed & $10(1.97)$ & $7(1.86)$ & $3(2.29)$ & 0.758 & $3(1.00)$ & $7(3.35)$ & 0.061 \\
\hline \multicolumn{4}{|c|}{ ESBL status of the isolated pathogens } & 0.061 & & & 0.302 \\
\hline $\operatorname{ESBL}(+)$ & $\begin{array}{c}138 \\
(39.09)\end{array}$ & $97(36.33)$ & $41(47.67)$ & & $79(41.58)$ & $59(36.92)$ & \\
\hline ESBL (-) & $\begin{array}{c}215 \\
(60.91)\end{array}$ & $170(63.67)$ & $45(52.33)$ & & $111(58.42)$ & $104(63.80)$ & \\
\hline
\end{tabular}

Notes: Mixed, meant infected by more than one bacteria; ESBL, Extended-spectrum $\beta$-lactamase.

\section{Association between MDR bacteria infection and clinical characteristics in liver cirrhosis patients}

According to the drug sensitivity analysis, 186 isolates were defined as MDR bacteria, and the percentage of MDR isolates was $36.61 \%$. In the current study, all the ESBL positive bacteria were MDR bacteria. We compared the clinical symptoms between patients infected by MDR bacteria and those infected by non-MDR bacteria. The results listed in Table 5 suggested that MDR bacteria infection was significantly correlated with elder age $(P=0.044)$, ICU admission $(P=0.003)$, infection history within 2 years $(P=0.033)$, and advanced Child-Pugh grade $(P=0.034)$. Furthermore, the patients infected by MDR bacteria were more likely to undergo septic shock $(P=0.000)$, inappropriate antibitics within $12 \mathrm{~h}(P=0.000)$, and poor survival within 30 days $(P=0.020)$ (Table 5). In addition, survival analysis suggested that the patients infected by MDR bacteria had poor survival, compared with those infected by non-MDR bacteria (log rank test, $P=0.020$ ) (Figure 1C).

\section{Risk factors for 30-day mortality in gram- negative bacterial bloodstream infection patients}

Cox regression model was applied to evaluate the risk factors for 30-mortality of patients. Through the univariate analyses, the ICU admission, nosocomial infection, Child-Pugh grade, combined with liver failure, septic shock, complications, WBC, serum neutrophil, appropriate antibiotics within $12 \mathrm{~h}$ and MDR bacteria infection were reported to be associated with 30-day mortality among cirrhosis patients developing to BSI $(P<0.05$ for all). Multivariate analyses suggested that nosocomial infection $(\mathrm{HR}=1.589,95 \% \mathrm{CI}=1.004-2.517$, $P=0.048)$ Child-Pugh grade $(\mathrm{HR}=2.471,95 \% \mathrm{CI}=1.279$ 4.772, $P=0.007)$, septic shock ( $\mathrm{HR}=1.966,95 \% \mathrm{CI}=1.228$ 3.146, $\quad P=0.005)$, complications $\quad(\mathrm{HR}=3.529, \quad 95 \%$ 
Table 3: Drug sensitivity analysis

\begin{tabular}{|c|c|c|c|}
\hline Antibiotics & Total & Sensitivity (n, \%) & $P$ value \\
\hline \multicolumn{4}{|c|}{ The fourth-generation cephalosporins } \\
\hline Cefepime & 462 & $351(75.97)$ & 0.000 \\
\hline \multicolumn{4}{|c|}{ The third-generation cephalosporins } \\
\hline Cefoperazone & 163 & $111(68.10)$ & 0.000 \\
\hline Cefotaxime & 198 & $128(64.65)$ & 0.000 \\
\hline Ceftazidime & 480 & $352(73.33)$ & 0.000 \\
\hline Ceftriaxone & 470 & $297(63.19)$ & 0.000 \\
\hline \multicolumn{4}{|c|}{ Quinolones } \\
\hline Gatifloxacin & 200 & $143(71.50)$ & 0.000 \\
\hline Levofloxacin & 474 & $333(70.25)$ & 0.000 \\
\hline \multicolumn{4}{|c|}{ Carbapenems } \\
\hline Imipenem & 485 & $464(95.67)$ & 0.000 \\
\hline Meropenem & 387 & $373(96.38)$ & 0.000 \\
\hline \multicolumn{4}{|c|}{$\beta$-lactamase inhibitors } \\
\hline Piperacillin/tazobactam & 467 & $428(91.65)$ & Reference \\
\hline Cefperazone/sulbactam & 405 & $364(89.88)$ & 0.117 \\
\hline \multicolumn{4}{|c|}{ Aminoglycosides } \\
\hline Amikacin & 473 & $457(96.62)$ & 0.000 \\
\hline
\end{tabular}

$\mathrm{CI}=2.140-5.818, P=0.000)$, and $\mathrm{WBC}(\mathrm{HR}=1.065,95 \%$ $\mathrm{CI}=1.018-1.114, P=0.006)$ were independent indicators for 30 -day mortality among the study population (Table 6).

\section{DISCUSSION}

BSI is one of the serious complications of liver cirrhosis, with high morbidity and mortality rates. Compared with non-cirrhosis patients, the occurrence of BSI is significantly high in liver cirrhosis. The underlying mechanisms may refer to two pathophysiological conditions: dysregulated intestinal bacterial translocation and immune dysfunction caused by cirrhosis. Patients with liver cirrhosis exhibit slow peristalsis of intestine and congestion of the gastrointestinal tract, which create a suitable condition for growth of pathogens. Moreover, the surveillance function of liver against bacteria is weaken in the cirrhosis cases. The interaction between the two pathophysiological conditions may lead to excessive growth of intestinal flora, thus causing the occurrence of BSI. Although the managements of cirrhosis have been improved, the incidence rate of BSI is still high [19]. Once the infection and multiple complications such as septic shock occur, it will be followed by organ failures. Thus, timely and appropriate antibiotic treatment is important for improving quality of life and outcomes in cirrhosis patients combined with BSI. The present study was carried out to evaluate the etiology of gram-negative bacterial infection in cirrhosis patients, as well as the antibiotic sensitivity of their isolates, which might guide empirical therapy.

In the present study, 30-day mortality was used to measure the primary outcomes of liver cirrhosis patients and the general clinical characteristics were compared between survivors and no-survivors. The results revealed that various factors including Child-Pugh score, BSI data, age, and therapeutic regimens were different between survivors and non-survivors. Child-Pugh score as a liver disease specific score was widely used to predict long and short term survival in cirrhosis patients, even among those combined with infection [20]. However, it was reported that besides the general scoring systems, the infection severity should also be considered when predicting prognosis in liver cirrhosis patients presenting infection [21]. In this study, we found that in addition to Child-Pugh score, septic shock, complications, WBC and hospital-acquired BSI were also independently correlated with 30-day survival rate among cirrhosis patients infected by gram negative bacteria. The conclusion informed that both liver diseases and infection played important 
roles in prognosis of cirrhosis patients who presented gram negative bacterial infection. Therefore, a novel model, which could predict liver disease and infection, was urgently needed for prognosis analysis in the study population.

The etiological distribution of cirrhosis patients was reported in a number of studies. In the study designed by
Campillo et al., gram-negative and positive bacteria as well as Candida albicans are cultured from the specimens of hospital-acquired infection patients [22]. A study carried out by Bartoletti et al. reports that the major cause for BSI is gram-negative bacteria, followed by gram-positive bacteria and Candida albicans [23]. However, a specific study on gram negative bacterial infection is absent,
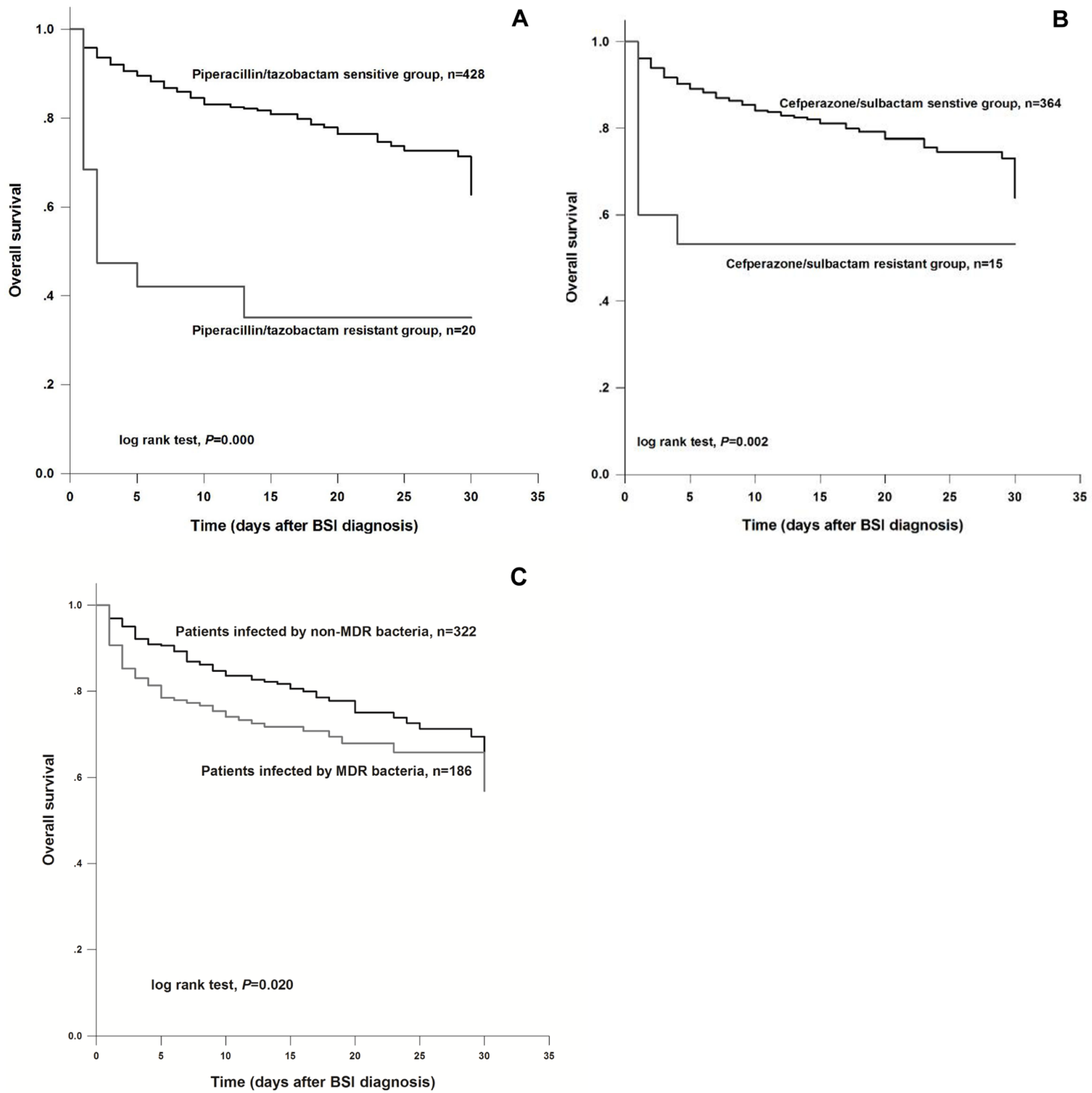

Figure 1: (A) Overall survival analysis for liver cirrhosis patients according to their susceptibility to piperacillin/ tazobactam. The results suggested that patients with drug resistance had a poor overall survival than those sensitive to piperacillin/ tazobactam (log rank test, $P=0.000$ ). (B) Survival curve for the study subjects according to their resistance to cefperazone/sulbactam. The curve showed that patients carrying cefperazone/sulbactam resistant pathogen underwent a lower survival rate than those carrying sensitive bacteria (log rank test, $P=0.002$ ). (C) Survival analysis for the cirrhosis cases infected by MDR. Analysis results demonstrated that the survival rate of liver cirrhosis cases infected by MDR bacteria was significantly low, compared with those infected by non-MDR bacteria (log rank test, $P=0.020)$. 
Table 4: The comparison of drug sensitivity between nosocomial BSI and community-acquired BSI

\begin{tabular}{|c|c|c|c|c|}
\hline & Total & Nosocomial BSI & Community-acquired BSI & $P$ value \\
\hline \multicolumn{5}{|c|}{ The fourth-generation cephalosporins } \\
\hline Cefepime & & & & 0.300 \\
\hline Sensitive & $351(75.97)$ & $195(73.58)$ & $156(79.19)$ & \\
\hline Mid-sensitive & $11(2.38)$ & $8(3.02)$ & $3(1.52)$ & \\
\hline Resistant & $100(21.65)$ & $62(23.40)$ & $38(19.29)$ & \\
\hline \multicolumn{5}{|c|}{ The third-generation cephalosporins } \\
\hline Cefoperazone & & & & 0.170 \\
\hline Sensitive & $111(68.10)$ & $56(62.22)$ & $55(75.34)$ & \\
\hline Mid-sensitive & $8(4.91)$ & $6(6.67)$ & $2(2.74)$ & \\
\hline Resistant & $44(26.99)$ & $28(31.11)$ & $16(21.92)$ & \\
\hline Cefotaxime & & & & 0.600 \\
\hline Sensitive & $128(64.65)$ & $76(64.96)$ & $52(64.20)$ & \\
\hline Mid-sensitive & $8(4.04)$ & $6(5.13)$ & $2(2.47)$ & \\
\hline Resistant & $62(31.31)$ & $35(29.91)$ & $27(33.33)$ & \\
\hline Ceftazidime & & & & 0.531 \\
\hline Sensitive & $352(73.33)$ & $202(71.63)$ & $150(75.76)$ & \\
\hline Mid-sensitive & $10(2.08)$ & $7(2.48)$ & $3(1.51)$ & \\
\hline Resistant & $118(24.58)$ & 73 (25.89) & 45 (22.73) & \\
\hline Ceftriaxone & & & & 0.655 \\
\hline Sensitive & $297(63.19)$ & $165(61.57)$ & $132(65.35)$ & \\
\hline Mid-sensitive & $14(2.98)$ & $9(3.36)$ & $5(2.47)$ & \\
\hline Resistant & $159(33.83)$ & 94 (35.07) & $65(32.18)$ & \\
\hline \multicolumn{5}{|c|}{ Quinolones } \\
\hline Gatifloxacin & & & & 0.928 \\
\hline Sensitive & $143(71.50)$ & 84 (71.19) & $59(71.95)$ & \\
\hline Mid-sensitive & $6(3.00)$ & $4(3.39)$ & $2(2.44)$ & \\
\hline Resistant & $51(25.50)$ & $30(25.42)$ & $21(25.61)$ & \\
\hline Levofloxacin & & & & 0.790 \\
\hline Sensitive & $333(70.25)$ & $192(69.31)$ & $141(71.57)$ & \\
\hline Mid-sensitive & $18(3.80)$ & $10(3.61)$ & $8(4.06)$ & \\
\hline Resistant & $123(25.95)$ & 75 (27.08) & $48(24.36)$ & \\
\hline \multicolumn{5}{|c|}{ Carbapenems } \\
\hline Imipenem & & & & 0.036 \\
\hline Sensitive & 464 (95.67) & 265 (93.97) & 199 (98.03) & \\
\hline Mid-sensitive & $4(0.83)$ & $2(0.71)$ & $2(0.98)$ & \\
\hline Resistant & $17(3.50)$ & $15(5.32)$ & $2(0.98)$ & \\
\hline
\end{tabular}

(Continued) 


\begin{tabular}{|c|c|c|c|c|}
\hline & Total & Nosocomial BSI & Community-acquired BSI & $P$ value \\
\hline Meropenem & & & & 0.038 \\
\hline Sensitive & $373(96.38)$ & $205(94.91)$ & $168(98.25)$ & \\
\hline Mid-sensitive & $6(1.55)$ & $3(1.39)$ & $3(1.75)$ & \\
\hline Resistant & $8(2.07)$ & $8(3.70)$ & $0(0.00)$ & \\
\hline \multicolumn{5}{|c|}{$\beta$-lactamase inhibitors } \\
\hline $\begin{array}{l}\text { Piperacillin/ } \\
\text { tazobactam }\end{array}$ & & & & 0.263 \\
\hline Sensitive & $428(91.65)$ & $245(90.07)$ & $183(93.85)$ & \\
\hline Mid-sensitive & $19(4.07)$ & $12(4.41)$ & $7(3.59)$ & \\
\hline Resistant & $20(4.28)$ & $15(5.51)$ & $5(2.56)$ & \\
\hline $\begin{array}{l}\text { Cefperazone/ } \\
\text { sulbactam }\end{array}$ & & & & 0.089 \\
\hline Sensitive & $364(89.88)$ & $200(87.34)$ & $164(93.18)$ & \\
\hline Mid-sensitive & $26(6.42)$ & $20(8.73)$ & $6(3.41)$ & \\
\hline Resistant & $15(3.70)$ & $9(3.93)$ & $6(3.41)$ & \\
\hline \multicolumn{5}{|c|}{ Aminoglycoside } \\
\hline Amikacin & & & & 0.317 \\
\hline Sensitive & $457(96.62)$ & $261(95.60)$ & $196(98.00)$ & \\
\hline Mid-sensitive & $6(1.27)$ & $5(1.83)$ & $1(0.50)$ & \\
\hline Resistant & $10(2.11)$ & $7(2.56)$ & $3(1.50)$ & \\
\hline
\end{tabular}

especially in China. In the current study, cirrhosis patients infected with gram negative bacteria were employed as study subjects. Results of analyses stated that Escherichia coli and Klebsiella pneumoniae were the major causes for gram-negative bacterial infection. The microbiological etiology was similar between survivors and non-survivors. The conclusions were consistent with the study performed by Bartoletti et al. [23].

Nosocomial infection was proved to be a risk factor for short and long-term mortality in cirrhosis patients developing to BSI [24]. Bert et al. reported that the microbiological distribution and therapeutic complications were significantly different between nosocomial BSI and community-acquired BSI [18]. However, the therapeutic regimens were similar between nosocomial and community-acquired BSI, which might be responsible for the high mortality in hospital-acquired BSI patients. In the present study, we found that the cirrhosis patients with advanced Child-Pugh grade, presenting liver failure, high WBC and serum neutrophil, or having infection history less than 2 years were more likely develop to nosocomial BSI. Moreover, the nosocomial infection was observed to be correlated with high mortality and inappropriate antibiotic regimens within $12 \mathrm{~h}$. All these results implied that nosocomial infection could aggravate the disease progression of liver cirrhosis, thus leading to limited therapeutic efficacy and dismal clinical outcomes. In addition, the acquisition sites of infection was adopted to compare the bacterial distribution and drug sensitivity. The distributions of Klebsiella pneumoniae, Pseudomonas aeruginosa, Enterobacter cloacae, Acinetobacter baumanii, and Stenotrophomonas maltophilia were markedly different between nosocomial and communityacquired gram-negative BSI. Furthermore, cox regression analysis suggested that nosocomial infection was an independent biomarker for 30-mortality of the collected patients. All the related results revealed that acquisition sits of infection could influence the outcomes of cirrhosis patients combined with gram-negative bacterial infection. A study scheduled by Cheong et al. proved that the bacterial distribution and outcomes were obviously different between nosocomial and community infection, which was consistent with our findings [25]. They also have discovered that third-generation cephalosporins sensitivities in hospital- and community- acquired BSI were different. However, drug sensitivity analyses in the current study demonstrated that except for carbapenems, antibiotic sensitivities were similar between nosocomial 
Table 5: The association between MDR BSI infection and clinical characteristics in liver cirrhosis patients

\begin{tabular}{|c|c|c|c|}
\hline Factors & $\begin{array}{l}\text { MDR infection } \\
(n=186,36.61 \%)\end{array}$ & $\begin{array}{l}\text { Non-MDR infection } \\
(\mathrm{n}=\mathbf{3 2 2}, \mathbf{6 3 . 3 9 \% )}\end{array}$ & $P$ values \\
\hline Gender & & & 0.067 \\
\hline male & $134(72.04)$ & $255(79.19)$ & \\
\hline female & $52(27.96)$ & $37(11.49)$ & \\
\hline Age (years) & $52.31 \pm 11.55$ & $50.19 \pm 11.36$ & 0.044 \\
\hline ICU & & & 0.003 \\
\hline yes & $42(22.58)$ & $40(12.42)$ & \\
\hline no & $144(77.42)$ & $282(87.58)$ & \\
\hline Nosocomial infection & & & 0.301 \\
\hline yes & $115(61.83)$ & $184(57.14)$ & \\
\hline no & $71(38.17)$ & $138(42.86)$ & \\
\hline $\begin{array}{l}\text { Infection history within } 2 \\
\text { years }\end{array}$ & & & 0.033 \\
\hline yes & $47(25.27)$ & $56(17.39)$ & \\
\hline no & $139(74.73)$ & $266(82.61)$ & \\
\hline SBP as BSI source & & & 0.170 \\
\hline yes & $82(44.09)$ & $122(37.89)$ & \\
\hline no & $104(55.91)$ & $200(62.11)$ & \\
\hline Child-Pugh grade & & & 0.034 \\
\hline $\mathrm{A}+\mathrm{B}$ & $67(36.02)$ & $147(45.65)$ & \\
\hline $\mathrm{C}$ & $119(63.98)$ & $175(54.35)$ & \\
\hline Combined with liver failures & & & 0.456 \\
\hline yes & $47(25.27)$ & $72(22.36)$ & \\
\hline no & $139(74.73)$ & $250(77.64)$ & \\
\hline Combined with liver cancer & & & 0.341 \\
\hline yes & $47(25.27)$ & $94(29.19)$ & \\
\hline no & $139(74.73)$ & $228(70.81)$ & \\
\hline Septic shock & & & 0.000 \\
\hline yes & $56(30.11)$ & $54(16.77)$ & \\
\hline no & $130(69.89)$ & $268(83.23)$ & \\
\hline Complications & & & 0.082 \\
\hline yes & $124(66.67)$ & $238(73.91)$ & \\
\hline no & $62(33.33)$ & $84(26.09)$ & \\
\hline $\mathrm{WBC}\left(\right.$ cells $\left.\times 10^{3} / \mu \mathrm{L}\right)$ & $7.19 \pm 6.83$ & $6.28 \pm 4.28$ & 0.065 \\
\hline Serum neutrophil (\%) & $0.71 \pm 0.15$ & $0.69 \pm 0.17$ & 0.095 \\
\hline $\begin{array}{l}\text { Appropriate antibiotics } \\
\text { within } 12 \mathrm{~h}\end{array}$ & & & 0.000 \\
\hline
\end{tabular}

(Continued) 


\begin{tabular}{lccc}
\hline Factors & $\begin{array}{c}\text { MDR infection } \\
(\mathbf{n = 1 8 6 , 3 6 . 6 1 \% )}\end{array}$ & $\begin{array}{c}\text { Non-MDR infection } \\
(\mathbf{n = 3 2 2 , 6 3 . 3 9 \% )}\end{array}$ & $\boldsymbol{P}$ values \\
\hline yes & $104(55.91)$ & $263(81.68)$ & \\
no & $82(44.09)$ & $59(18.32)$ & 0.020 \\
30-day survival status & & & \\
survivor & $127(68.28)$ & $250(77.64)$ & 0.000 \\
non-survivor & $59(31.72)$ & $72(22.36)$ & \\
ESBL & 138 & 0 & \\
positive & 11 & 204 & \\
negative & &
\end{tabular}

Table 6: Risk factors for 30-mortality in liver cirrhosis patients infected with gram-negative bacteria

\begin{tabular}{|c|c|c|c|c|}
\hline \multirow[t]{2}{*}{ Factors } & \multicolumn{2}{|c|}{ Univariate analyses } & \multicolumn{2}{|c|}{ Multivariate analyses } \\
\hline & HR $(95 \% C I)$ & $P$ & HR (95\%CI) & $P$ \\
\hline Gender (male vs female) & $0.770(0.525-1.130)$ & 0.182 & & \\
\hline Age (years) & $1.010(0.995-1.026)$ & 0.207 & & \\
\hline ICU (yes vs no) & $4.280(3.021-6.065)$ & 0.000 & & \\
\hline $\begin{array}{l}\text { Nosocomial infection } \\
\text { (yes vs no) }\end{array}$ & $1.724(1.185-2.508)$ & 0.004 & $1.589(1.004-2.517)$ & 0.048 \\
\hline $\begin{array}{l}\text { Infection history within } 2 \text { years } \\
\text { (yes vs no) }\end{array}$ & $1.198(0.801-1.793)$ & 0.379 & & \\
\hline $\begin{array}{l}\text { SBP as BSI source } \\
\text { (yes vs no) }\end{array}$ & $1.258(0.892-1.774)$ & 0.191 & & \\
\hline Child-Pugh grade $(\mathrm{C}$ vs $\mathrm{A}+\mathrm{B})$ & $4.017(2.492-6.475)$ & 0.000 & $2.471(1.279-4.772)$ & 0.007 \\
\hline $\begin{array}{l}\text { Combined with liver failures } \\
\text { (yes vs no) }\end{array}$ & $3.244(2.297-4.579)$ & 0.000 & & \\
\hline $\begin{array}{l}\text { Combined with liver cancer } \\
\text { (yes vs no) }\end{array}$ & $1.251(0.832-1.882)$ & 0.282 & & \\
\hline Septic shock (yes vs no) & $5.454(3.864-7.698)$ & 0.000 & $1.966(1.228-3.146)$ & 0.005 \\
\hline Complications (yes vs no) & $6.444(4.461-9.310)$ & 0.000 & $3.529(2.140-5.818)$ & 0.000 \\
\hline $\mathrm{WBC}\left(\right.$ cells $\left.\times 10^{3} / \mu \mathrm{L}\right)$ & $1.084(1.060-1.109)$ & 0.000 & $1.065(1.018-1.114)$ & 0.006 \\
\hline Serum neutrophil (\%) & $4.188(1.354-12.960)$ & 0.013 & & \\
\hline $\begin{array}{l}\text { Appropriate antibiotics within } 12 \mathrm{~h} \\
\text { (no vs yes) }\end{array}$ & $1.575(1.104-2.248)$ & 0.012 & & \\
\hline $\begin{array}{l}\text { ESBL status } \\
\text { (positive vs negative) }\end{array}$ & $1.443(0.945-2.203)$ & 0.090 & & \\
\hline $\begin{array}{l}\text { MDR bacteria infection } \\
\text { (yes vs no) }\end{array}$ & $1.539(1.091-2.172)$ & 0.014 & & \\
\hline
\end{tabular}

Notes: BSI, Bloodstream infection; ICU, Intensive care unit; SBP, Spontaneous bacterial peritonitis; WBC, White blood cell; ESBL, Extended-spectrum $\beta$-lactamase. 
and community-acquired infection. Various factors including different hospitals and study populations might contribute to the differences. Therefore, a multicenters study was needed to evaluate the effects of nosocomial infection in cirrhosis patients.

Antibiotic management was crucially important for outcomes in cirrhosis patients combined with infection. Unfortunately, with the increasing drug resistant bacteria, anti-bacteria treatments became difficult [26]. In the current study, 36.61\% isolates were MDR bacteria. MDR bacteria were frequently isolated from elder patients, ICU cases, and those diagnosed with advanced Child-Pugh grade. Furthermore, liver cirrhosis cases infected by MDR pathogens were more likely to undergo inappropriate antibiotic treatments and unsatisfactory clinical outcomes. Therefore, a better understanding of the antibiotic sensitivity is key for infection treatments. In the present study, the sensitivity of frequently-used antibiotics based on gram-negative bacteria isolated from the study population was compared, and the results demonstrated that the isolates showed high sensitivity to carbapenem, aminoglycoside, and $\beta$-lactamase inhibitor antibiotics. Compared with $\beta$-lactamase inhibitors antibiotics, the drug sensitivities of carbapenem and aminoglycosides were significantly high, while other antibiotics such as cephalosporins, quinolones exhibited low antibacterial activity. Aminoglycosides antibiotics were frequently used for the infection caused by aerobic gram negative bacteria, but the nephrotoxicity, ototoxicity and drug resistance might limit its wide use $[27,28]$. At the present time, carbapenems represented a last line for treatments of multidrugs resisting gramnegative pathogens, which was often used in empirical therapy [29]. However, growing evidences had proved that the excessive use of carbapenems could promote the prevalence of carbapenems resistant pathogens [30, 31]. Thus, an effective antibiotic which could serve as carbapenems alternatives in treatment of infection was urgently needed. In this study, the $\beta$-lactamase inhibitor antibiotics showed a high antibacterial activity to gramnegative pathogens. A meta-analysis conducted by Shiber et al. have demonstrated that there were no difference in efficacy between $\beta$-lactamase inhibitors and carbapenms in treatment of infections. Moreover, no serious side effects were observed in $\beta$-lactamase inhibitor treatments [32]. All of the related data revealed that $\beta$-lactamase inhibitor antibiotics showed a high antibacterial activity without serious side effects, which might be the first choice for empirical treatments of gram-negative bacterial infection.

There were still several limitations in the current study. First, we only investigated the microbiological characteristics and clinical outcomes of gram-negative bacterial infection cases. However, growing evidences have suggested that the prevalence of the gram-positive bacteria like Staphylococcus exhibited obviously increased trend in BSI cases during the last 10 years, due to the increased application of invasive procedures and exogenous route of infection [33]. Therefore, it is necessary to collect more liver cirrhosis combined BSI cases to roundly investigate the microbiological etiology of BSI in Chinese population. Second, we did not investigate the pharmacodynamics characteristics of $\beta$-lactamase inhibitor antibiotics for treatment BSI in the current study. The conditions of liver cirrhosis patients developing BSI are often critical, and appropriate empirical treatments are pivotal for therapeutic effects. The study scheduled by Zelenitsky et al. reported that for ICU patients presenting infection, piperacillin-tazobactam $3.375 \mathrm{~g}$ every $6 \mathrm{~h}$, with prolonged infusion times of $0.5 \mathrm{~h}$ could significantly control infection condition [34]. Ambrose et al. found that for patients infected by $E$. coli, the optimal regimen of piperacillin-tazobactam was infusion with $3.375 \mathrm{~g}$ every $4 \mathrm{~h}$, and $3.375 \mathrm{~g}$ every $6 \mathrm{~h}$ for $K$. pneumoniae infection [35]. The prolonged infusion is necessary for critically ill patients [36]. A retrospective cohort study carried out by Yost et al. indicated that extended-infusion of piperacillintazobactam could significantly improve the survival and lower the mortality among patients infected by gramnegative bacteria [37]. The administration experiences might provide guidance for application of $\beta$-lactamase inhibitor antibiotics in clinic. In addition, cox analysis was used to identify the risk factors of 30-day mortality among the study population. The clinical factors were detected when BSI onset. However, some of the parameters, such as WBC, complications, septic shock, might change during the disease progression, thereby causing bias to the final results. In a word, further investigations are still required to address the above issues.

In conclusion, Escherichia coli and Klebsiella pneumoniae are the prevalent isolates from gram-negative bacterial bloodstream infection episodes in cirrhosis patients. The clinical characteristics and etiological distribution may be influenced by the acquisition sites of infection. Nosocomial infection, Child-Pugh grade, septic shock, complications and WBC are independent biomarkers for 30-mortality in the study populations. $\beta$-lactamase inhibitor antibiotics show a high antibacterial activity, which may be widely used in empirical therapy.

\section{MATERIALS AND METHODS}

\section{Study subjects}

The present research was a retrospective cohort study. The patients who were hospitalized for liver cirrhosis and developed to gram-negative bacterial bloodstream infection in Beijing 302 hospital from October, 2010 to January, 2015 were recruited in our study. The present study was based on adult group and the patients aged over 16 were collected. In addition, the clinical information of recruited patients was extracted from the medical records, such as demographic data, 
hospitalization information, complications, BSI data, microbiological testing results, and laboratory data. In those patients who developed multiple BSIs during hospital duration, only the first episode was used for analysis. The current study was approved by the ethic committee of the hospital. All of the patients or their families signed the informed consents.

\section{Data collection}

Data were extracted from the clinical records of eligible patients using a standardized data form. The following information was collected: demographic characteristics (gender and age), hospitalization unit, cause of cirrhosis, Child-Pugh score, BSI data (history within 2 years, BSI source, days for hospitalization before BSI onset, initial symptoms, complications, septic shock), laboratory data (WBC, serum neutrophil), bacterial distributions, results of drug sensitivity test and empirical antibiotic regimens. The 30 -day mortality was used to evaluate the primary outcomes of the patients.

\section{Diagnosis criteria}

The international classification of disease was employed to identify the diagnosis of cirrhosis and associated risk factors. The liver disease severity was confirmed by Child-Pugh score [38]. If the patients appeared one or more the following symptoms, the patients were considered to have an infection: while blood cells appearing in normally sterile body fluids; perforated viscus; pneumonia associated with purulent sputum demonstrated by radiographic imaging; some other symptoms caused by infection, such as ascending cholangitis [39]. Blood samples were collected each infected or seemingly infected case. Blood culture results of the patients were collected by following the standard operations. Gram-negative bacterial bloodstream infection was defined as the growth of any aerobic gram-negative bacteria in the blood culture. The patients who presented infection over $48 \mathrm{~h}$ after admission to the hospital were defined as nosocomial infection. The center for disease control and prevention criteria were applied to confirm the primary source of BSI [40]. Whether SBP was a source of BSI was determined by the Fridman's criteria [41]. The therapy was considered to be appropriate if the used drug could inhibit the activity of isolated pathogens in vitro according to drug sensitivity test. The definition of MDR was according to Magiorakos et al [42]. If the isolates show non-susceptibility to at least one agent in three or more antimicrobial categories in vitro, the isolates were defined as MDR.

\section{Statistical analysis}

The continuous variables were presented as mean \pm standard deviation (SD) and were compared by Student's t test. The categorical data were analyzed by chi-square test. The clinical characteristics of included patients were compared based on their survival status within 30 days after infection diagnosis, infection acquisition sites, as well as the extended-spectrum $\beta$-lactamase (ESBL) status of their cultures. In addition, we also compared the clinical symptoms between the patients infected by MDR bacteria and those infected by non-MDR bacteria. Survival curves were calculated according to Kaplan-Meier method with log rank test. Cox regression analysis was used to identify the risk factors and independent indicators for 30day mortality of the study subjects. SPSS 18.0 software was used for all statistical analyses and $P<0.05$ was considered as statistical significance in the present study.

\section{CONFLICTS OF INTEREST}

The authors declare no conflicts of interest.

\section{GRANT SUPPORT}

None.

\section{REFERENCES}

1. Zhou J, Deng Y, Yan L, Zhao H, Wang G. Serum plateletderived growth factor BB levels: a potential biomarker for the assessment of liver fibrosis in patients with chronic hepatitis B. Int J Infect Dis. 2016; 49:94-99.

2. Cui Y, Jia J. Update on epidemiology of hepatitis B and C in China. J Gastroenterol Hepatol. 2013; 28:7-10.

3. Jalan R, Fernandez J, Wiest R, Schnabl B, Moreau R, Angeli P, Stadlbauer V, Gustot T, Bernardi M, Canton R, Albillos A, Lammert F, Wilmer A, et al. Bacterial infections in cirrhosis: a position statement based on the EASL Special Conference 2013. J Hepatol. 2014; 60:1310-1324.

4. Thulstrup AM, Sorensen HT, Schonheyder HC, Moller JK, Tage-Jensen U. Population-based study of the risk and short-term prognosis for bacteremia in patients with liver cirrhosis. Clin Infect Dis. 2000; 31:1357-1361.

5. Fernandez J, Gustot T. Management of bacterial infections in cirrhosis. J Hepatol. 2012; 56:S1-S12.

6. Park H, Jang KJ, Jang W, Park SH, Park JY, Jeon TJ, Oh TH, Shin WC, Choi WC, Sinn DH. Appropriate empirical antibiotic use and 30-d mortality in cirrhotic patients with bacteremia. World J Gastroenterol. 2015; 21:3587-3592.

7. Botwin GJ, Morgan TR. Bacterial infections in cirrhosis. Hepatol Int. 2014; 8:467-474.

8. Stryjewski ME, Boucher HW. Gram-negative bloodstream infections. Int J Antimicrob Agents. 2009; 34:S21-S25.

9. Fernandez J, Acevedo J, Castro M, Garcia O, de Lope CR, Roca D, Pavesi M, Sola E, Moreira L, Silva A, SevaPereira T, Corradi F, Mensa J, et al. Prevalence and risk factors of infections by multiresistant bacteria in cirrhosis: a prospective study. Hepatology. 2012; 55:1551-1561. 
10. Folgori L, Livadiotti S, Carletti M, Bielicki J, Pontrelli G, Ciofi Degli Atti ML, Bertaina C, Lucignano B, Ranno S, Carretto E, Muraca M, Sharland M, Bernaschi P. Epidemiology and clinical outcomes of multidrug-resistant, gram-negative bloodstream infections in a European tertiary pediatric hospital during a 12-month period. Pediatr Infect Dis J. 2014; 33:929-932.

11. Acevedo J. Multiresistant bacterial infections in liver cirrhosis: clinical impact and new empirical antibiotic treatment policies. World J Hepatol. 2015; 7:916-921.

12. Merli M, Lucidi C, Giannelli V, Giusto M, Riggio O, Falcone M, Ridola L, Attili AF, Venditti M. Cirrhotic patients are at risk for health care-associated bacterial infections. Clin Gastroenterol Hepatol. 2010; 8:979-985.

13. Novovic S, Semb S, Olsen H, Moser C, Knudsen JD, Homann C. First-line treatment with cephalosporins in spontaneous bacterial peritonitis provides poor antibiotic coverage. Scand J Gastroenterol. 2012; 47:212-216.

14. Tandon P, Delisle A, Topal JE, Garcia-Tsao G. High prevalence of antibiotic-resistant bacterial infections among patients with cirrhosis at a US liver center. Clin Gastroenterol Hepatol. 2012; 10:1291-1298.

15. Piano S, Romano A, Rosi S, Gatta A, Angeli P. Spontaneous bacterial peritonitis due to carbapenemase-producing Klebsiella pneumoniae: the last therapeutic challenge. Eur J Gastroenterol Hepatol. 2012; 24:1234-1237.

16. Zhao X, Li S, Sun X, Liu S, Duan F. Risk factors for hospital-acquired infection in cancer patients in a central Chinese hospital. Am J Infect Control. 2016; 44:e163-165.

17. Xia J, Gao J, Tang W. Nosocomial infection and its molecular mechanisms of antibiotic resistance. Biosci Trends. 2016; 10:14-21.

18. Bert F, Andreu M, Durand F, Degos F, Galdbart JO, Moreau R, Branger C, Lambert-Zechovsky N, Valla D. Nosocomial and community-acquired spontaneous bacterial peritonitis: comparative microbiology and therapeutic implications. Eur J Clin Microbiol Infect Dis. 2003; 22:10-15.

19. Xie Y, Tu B, Xu Z, Zhang X, Bi J, Zhao M, Chen W, Shi L, Zhao P, Bao C, Qin E, Xu D. Bacterial distributions and prognosis of bloodstream infections in patients with liver cirrhosis. Sci Rep. 2017; 7:11482. https://doi.org/10.1038/ s41598-017-11587-1.

20. Peng Y, Qi X, Dai J, Li H, Guo X. Child-Pugh versus MELD score for predicting the in-hospital mortality of acute upper gastrointestinal bleeding in liver cirrhosis. Int $\mathrm{J}$ Clin Exp Med. 2015; 8:751-757.

21. Viasus D, Garcia-Vidal C, Castellote J, Adamuz J, Verdaguer R, Dorca J, Manresa F, Gudiol F, Carratala J. Community-acquired pneumonia in patients with liver cirrhosis: clinical features, outcomes, and usefulness of severity scores. Medicine (Baltimore). 2011; 90:110-118.

22. Campillo B, Dupeyron C, Richardet JP. Epidemiology of hospital-acquired infections in cirrhotic patients: effect of carriage of methicillin-resistant Staphylococcus aureus and influence of previous antibiotic therapy and norfloxacin prophylaxis. Epidemiol Infect. 2001; 127:443-450.

23. Bartoletti M, Giannella M, Caraceni P, Domenicali M, Ambretti S, Tedeschi S, Verucchi G, Badia L, Lewis RE, Bernardi M, Viale P. Epidemiology and outcomes of bloodstream infection in patients with cirrhosis. J Hepatol. 2014; 61:51-58.

24. Hoenigl M, Wagner J, Raggam RB, Prueller F, Prattes J, Eigl S, Leitner E, Honigl K, Valentin T, Zollner-Schwetz I, Grisold AJ, Krause R. Characteristics of hospital-acquired and community-onset blood stream infections, South-East Austria. PLoS One. 2014; 9:e104702.

25. Cheong HS, Kang CI, Lee JA, Moon SY, Joung MK, Chung DR, Koh KC, Lee NY, Song JH, Peck KR. Clinical significance and outcome of nosocomial acquisition of spontaneous bacterial peritonitis in patients with liver cirrhosis. Clin Infect Dis. 2009; 48:1230-1236.

26. Moehring RW, Sloane R, Chen LF, Smathers EC, Schmader KE, Fowler VG Jr, Weber DJ, Sexton DJ, Anderson DJ. Delays in appropriate antibiotic therapy for gram-negative bloodstream infections: a multicenter, community hospital study. PloS one. 2013; 8:e76225.

27. Edson RS, Terrell CL. The aminoglycosides. Mayo Clin Proc. 1999; 74:519-528.

28. Namazi S, Sagheb MM, Hashempour MM, Sadatsharifi A. Usage pattern and serum level measurement of amikacin in the internal medicine ward of the largest referral hospital in the south of Iran: a pharmacoepidemiological study. Iran J Med Sci. 2016; 41:191-199.

29. Martirosov DM, Lodise TP. Emerging trends in epidemiology and management of infections caused by carbapenem-resistant Enterobacteriaceae. Diagn Microbiol Infect Dis. 2016; 85:266-275.

30. Harris PN, Tambyah PA, Paterson DL. beta-lactam and beta-lactamase inhibitor combinations in the treatment of extended-spectrum beta-lactamase producing Enterobacteriaceae: time for a reappraisal in the era of few antibiotic options? Lancet Infect Dis. 2015; 15:475-485.

31. Rodriguez-Bano J, Navarro MD, Retamar P, Picon E, Pascual A. beta-Lactam/beta-lactam inhibitor combinations for the treatment of bacteremia due to extended-spectrum betalactamase-producing Escherichia coli: a post hoc analysis of prospective cohorts. Clin Infect Dis. 2012; 54:167-174.

32. Shiber S, Yahav D, Avni T, Leibovici L, Paul M. betaLactam/beta-lactamase inhibitors versus carbapenems for the treatment of sepsis: systematic review and meta-analysis of randomized controlled trials. J Antimicrob Chemother. 2015; 70:41-47.

33. Bartoletti M, Giannella M, Lewis RE, Viale P. Bloodstream infections in patients with liver cirrhosis. Virulence. 2016; 7:309-319.

34. Zelenitsky SA, Ariano RE, Zhanel GG. Pharmacodynamics of empirical antibiotic monotherapies for an intensive care unit (ICU) population based on Canadian surveillance data. J Antimicrob Chemother. 2011; 66:343-349. 
35. Ambrose PG, Bhavnani SM, Jones RN. Pharmacokineticspharmacodynamics of cefepime and piperacillin-tazobactam against Escherichia coli and Klebsiella pneumoniae strains producing extended-spectrum beta-lactamases: report from the ARREST program. Antimicrob Agents Chemother. 2003; 47:1643-1646.

36. Harris PN, Tambyah PA, Paterson DL. beta-lactam and beta-lactamase inhibitor combinations in the treatment of extended-spectrum beta-lactamase producing Enterobacteriaceae: time for a reappraisal in the era of few antibiotic options? Lancet Infect Dis. 2015; 15:475-485.

37. Yost RJ, Cappelletty DM. The Retrospective Cohort of Extended-Infusion Piperacillin-Tazobactam (RECEIPT) study: a multicenter study. Pharmacotherapy. 2011; 31:767-775.

38. Suk KT, Baik SK, Yoon JH, Cheong JY, Paik YH, Lee CH, Kim YS, Lee JW, Kim DJ, Cho SW, Hwang SG, Sohn JH, Kim MY, et al. Revision and update on clinical practice guideline for liver cirrhosis. Korean J Hepatol. 2012; 18:1-21.

39. Thabut D, Massard J, Gangloff A, Carbonell N, Francoz C, Nguyen-Khac E, Duhamel C, Lebrec D, Poynard T, Moreau
R. Model for end-stage liver disease score and systemic inflammatory response are major prognostic factors in patients with cirrhosis and acute functional renal failure. Hepatology. 2007; 46:1872-1882.

40. Horan TC, Andrus M, Dudeck MA. CDC/NHSN surveillance definition of health care-associated infection and criteria for specific types of infections in the acute care setting. Am J Infect Control. 2008; 36:309-332.

41. Friedman ND, Kaye KS, Stout JE, McGarry SA, Trivette SL, Briggs JP, Lamm W, Clark C, MacFarquhar J, Walton AL, Reller LB, Sexton DJ. Health care--associated bloodstream infections in adults: a reason to change the accepted definition of community-acquired infections. Ann Intern Med. 2002; 137:791-797.

42. Magiorakos AP, Srinivasan A, Carey RB, Carmeli Y, Falagas ME, Giske CG, Harbarth S, Hindler JF, Kahlmeter G, Olsson-Liljequist B, Paterson DL, Rice LB, Stelling J, et al. Multidrug-resistant, extensively drug-resistant and pandrug-resistant bacteria: an international expert proposal for interim standard definitions for acquired resistance. Clin Microbiol Infect. 2012; 18:268-281. 